\title{
US FOREIGN POLICY IN RESTORING DIPLOMATIC RELATIONS WITH CUBA IN 2015-2016
}

\author{
Florentina Wulandari Maria Alexandra \\ International Relations, Universitas Kristen Indonesia, Jakarta, Indonesia \\ alexandra.florentina87@gmail.com
}

\begin{abstract}
At the end of 2014, the United States, under the leadership of President Barack Obama, decided to improve relations with Cuba. The relationship between the two countries has a long history. After 53 years of severing diplomatic ties with Cuba, America finally made a change through the policy of diplomatic relations improvement that began in 2015. This study analyzes the background that encourages the restoration of political ties between the United States and Cuba, examining the implementation of foreign policy forms between the two countries As a result of the restoration of diplomatic relations between the United States and Cuba through diplomatic channels. This research uses foreign policy theory and the theory of international pathways. The research method used is qualitative research with a secondary data source, with a data collection technique through a literature study. The study found that in the policy of restoring the diplomatic relations between the United States and Cuba happened for three main reasons, the first one. President Obama realized that US sanctions to Cuba is a policy that is not successful; the United States no longer wants to lose the market, which was very promising in Cuba. And also, the United States has a ton amount of pressure internationally and domestically, asking them to recover their relations with Cuba. These reasons ultimately implemented through diplomatic channels by both countries. They have implications such as increased bilateral visits, increased investment, and business as well as cultural exchange through communities and students.
\end{abstract}

Keywords: Foreign Policy, United States, Cuba, Re-establishment Diplomatic Relations

DOI: /10.33541/sp.v20i2.1459

Sociae Polites : Majalah Ilmiah Sosial Politik

Faculty of Social and Political Science, Universitas Kristen Indonesia

ISSN 1410-3745 print/ ISSN 2620-4975 online

Volume 20, Number 2 (July - December 2019)

Pages 93-114 


\section{Introduction}

\subsection{Background}

The United States (US), as one of the superpowers, has always been a spotlight in the international world, especially concerning other countries on the global stage. Even though it is the main spotlight on the international scene, the United States has always dared to issue attitudes and decisions that are sometimes at odds with global desires. In some cases, such as the severance of diplomatic relations, history records that the United States has severed diplomatic ties with several countries such as the People's Republic of China, Vietnam and Cuba.

Termination of diplomatic relations is considered unfavorable for the two countries involved because it will have an impact on political, economic to social and cultural ties. Termination of diplomatic relations between the United States and Cuba is long and has received various responses globally. In addition to the severance of diplomatic relations, the United States also sanctioned an embargo on Cuba.

The US embargo on Cuba includes a trade, economic and financial embargo established since October 1960 (almost two years after the Batista regime get overthrown in the Cuban Revolution). This embargo was adopted after Cuba nationalized the property of US residents and companies. This embargo was codified in the Cuban Democracy Act in 1993 to impose sanctions on Cuba as long as the Cuban government continued to reject the move towards democratization and greater respect for human rights.

In 1996, Congress approved the Helms-Burton Act, which increasingly restricted the population of the United States from doing business in Cuba and mandated restrictions on assisting the government in Havana unless several claims against the Cuban government fulfilled. In 1999, United States President Bill Clinton further strengthened the embargo by banning overseas US company branches from trading with Cuba.

This embargo is the longest trade embargo in modern history. Despite the blockade, the United States remains the fifth largest exporter to Cuba. However, Cuba must pay in cash for all imports because credit is not permitted. Whereas, based on historical records, the United States and Cuba have had good trade cooperation relations starting from colonialism until finally, Cuba won independence from Spain.

The cooperative relationship between the United States and Cuba has existed since the $19^{\text {th }}$ century. However, the two neighboring countries experienced dynamics in their cooperative relations, even tensions between the two since 1959 (The Aspen Institute 2000). The successful Cuban Revolution in 1959 made the United States aware of establishing bilateral relations with the interim government in Cuba at that time. A closed visit by Fidel Castro to the United States on April 15 26, 1959, to meet vice president Richard Nixon signaled that there were reasonable efforts from both parties to establish bilateral relations.

However, after the closed visit, Cuba's bilateral relations with the United States experienced a huge setback. Two main arguments explain the deterioration of Cuba's relations with the United States since 1959. First, the decline of Cuba's relations with the United States is inseparable from one of the strategic objectives of the United States about facing the risk of communist influence, and this is one of the disadvantages for Cuban socialists. Cuba became synonymous with communism from the perspective of the United 
States. The second argument is that the Cuban government makes policies that interfere with the interests of US capital. The land reform policy in Cuba is undoubtedly very unfavorable for the United States.

In May 1960, the United States stopped giving aid to Cuba, and the United States began imposing a trade embargo on Cuba. The climax was on January 3, 1961, and The United States broke off diplomatic relations with Cuba. A thrilling history of the relations between the United States and Cuba to date is the fact that relations between the two have never proceeded smoothly; for more than 53 years, the two countries have always been at odds. The intervention carried out by the United States against Cuba is almost the same as that carried out by the United States against other Latin American countries. Both political interference and economic intervention. It gets proven during the reign of Fulgencio Batista, Cuba's dependence on the United States was very high because Batista needed to maintain his power at that time with the support of the United States. But that has given the United States a chance to interfere in Cuba's domestic politics so that all decisions taken by Batista, such as allowing US multinational companies to invest, are not always for the good of Cuba. Still, there is also a mission of the United States in it.

Ten US presidents from Dwight Eisenhower to George W. Bush were unable to change the attitude of the US foreign policy towards Cuba. But in the era of Barack Obama, change began. Barack Obama began to talk about the future of US relations with Cuba since his campaign for the second time as a candidate for the incumbent President of the United States at that time. On January 20, 2009, Barack Husein Obama or commonly known as Barack Obama, was officially appointed as the 44th president of the United States. The first black President for the United States of African-American descent attracted international attention from the campaign period to successfully surpassing John McCain as a Republican presidential candidate. Barack Obama's popularity has increased dramatically. The citizens of the United States and the international community are waiting for the changes that Barack Obama will present through US foreign policies that always voiced during the campaign period, especially the US foreign policy towards Cuba.

Raising the title of US Foreign Policy in the context of Restoring Diplomatic Relations with Cuba in 2015-2016, the researcher aims to provide an overview of the background of the emergence of US foreign policy in the context of restoring diplomatic relations with Cuba in 2015-2016 until the implementation and implications of the system. The researcher will look at it from the perspective of the diplomatic path used by the United States in carrying out this policy of restoring diplomatic relations with Cuba. The researcher will also discuss the real form of implementing the system. This is important for this research because the foreign policy initiated by the United States in 2014 will give a new color to the pattern of international relations and dynamics in the coming year both bilaterally between the United States and Cuba as well as regionally and internationally.

\subsection{Research Question}

Based on the background described, the formulation of the problem of this research: 
1. What is the background for the United States to restore diplomatic relations with Cuba in 2015-2016?

2. What are the overseas paths taken by the United States in implementing the policy of restoring diplomatic relations with Cuba?

3. What are the implications of the system of restoring external diplomatic ties to the United States and Cuba?

This research hoped to be able to contribute ideas and input for the development of social science and political science in general and, specifically, international relations science. The focus of discussing US Foreign Policy Policy in the context of Restoring Diplomatic Relations with Cuba in 2015-2016 hoped to be able to contribute thoughts and perspectives in studying a phenomenon of international relations. Research on US Foreign Policy in the framework of Restoring Diplomatic Relations with Cuba in 2015-2016 will provide practical benefits in the form of a new perspective.

\section{Literature Review}

Two past research compare to this one. The first was (Gemma and Zawatsky) in 2015, the study investigated the normalization of diplomatic relations between the United States and Cuba. This research investigates the normalization of diplomatic relations between the United States and Cuba by first examining the causes of the previous normalization with Vietnam and China. Then the factors that are key to the normalization process are identified. These factors include political rotation, economic interests, other special pressure groups, public sentiment, and the Lawnmower Effect.

The Lawnmower Effect is a situation where one or two countries try to re-open diplomatic relations because they continually fail to establish relationships due to fundamental political issues. This study uses the Multiple Streams Framework (policy formulation theory) to evaluate the normalization process. In this theory, there is a "policy window," which focuses and resources on an issue. In the case of US-Cuban relations, the three schools gathered to create a policy window, due to some pressure international. From this research, it can get concluded as an evaluation of the current state and progress of the subsequent US-Cuban normalization process.

The other previous research was Cuba-US Relations penalizations and Its Challenges, written by Margaret E. Crahan and Soraya M. Castro Marino in 2016 (Crahan and Marino 2016). This study addresses two critical questions, the first to what extent Cuba's foreign policy contributes to the process of normalization and improvement of relations with the United States and secondly who are the main "spoilers" actors of the process towards this normalization.

John Coatsworth, an economic historian at Columbia University, answered the first question of this research by suggesting that Cuba had a choice between a balancing strategy or foreign policy bandwagoning. The first involves mobilizing domestic and international support to achieve a level of equilibrium with the strength and influence of the United States, which Coatsworth affirmed as the path chosen by Cuba since 1959. Coatsworth 
asserted that several countries in the Caribbean region had achieved the right balance like Cuba, even at a reasonable cost significant. The battle in railroad manufacturing also recognizes the asymmetry of strength between the countries of the United States, the Caribbean, and Central America, which encourages these countries to acknowledge their particular limitations and accept the restrictions imposed by the United States.

These restrictions indeed become obstacles in making their domestic and informal policies. The aim is to achieve a measure of respect as a sovereign state in return for recognizing the dominance and leadership of the United States. Coatsworth's strategy seems to be likely to impose obstacles in domestic policy-making, which are very problematic for governments that intend to undertake major or radical reforms. The study concludes that with the restoration of the last US-Cuban relationship, it may shift from a balancing strategy to a strategy to compete with some recognition of the global and regional interests of the United States in exchange for respect for the United States. Against Cuba.

Global and regional interests are the reason for US respect for Cuba's system and autonomy in terms of internal political, economic, and social policies. Coatsworth believes that the United States stated that there is no intention for a regime change. That with its explicit insistence on determining what the goals of the Cuban transition should be, the United States has at least rhetorically re-opened its past policies aimed at regime change. This study argues that the question for Cuba is what strategies and mechanisms are best for ensuring Cuba's success in pursuing its interests.

"Spoiling the Spoilers" is a challenge put forth by Philip Brenner and Colleen Scribner in their analysis of what could hinder or thwart the process towards normalization. Starting with an examination of the factors that have identified as facilitating standardization, they cite the effects of adjustments in the international system, cultural similarity, political will of influential leaders, regime change, longevity and severity of relations, catalysts, and economic problems. Spoilers contributed to the complexity of the process towards normalization, which complicates the hammer of some agreements and neglecting previous policies and regulations. Furthermore, Brenner and Scribner conclude that there is no guarantee that the process towards normalization will not get reversed as happened in other cases. Changing circumstances due to the election of the United States on November 8, 2016, certainly gave a more sophisticated impression than in the first two years of the process towards normalization.

This research seeks to continue and deepen the dialogue established over the years, which evaluates the Cuban-US situation. Relations in all complexities and contradictions between the two countries. This research shows that not only among experts, but also between citizens of both countries, a strong disposition to work towards normalization even though there is a legacy, differences, and challenges current and painful future.

The two previous studies described above are a specific difference from the research that will be examined in the United States Foreign Policy research in the context of Restoring Diplomatic Relations with Cuba in 2015-2016. In this study, researchers will focus on analyzing the background that drives the implementation of US foreign policy in the context of restoring diplomatic relations with Cuba. Then in analyzing the diplomatic channels used and implemented from the system of restoring diplomatic ties between the United States and Cuba. Finally, explaining the policy implications of restoring diplomatic relations to the two countries. This research will use two main theories, namely Foreign 
Policy theory, which includes policy making and Multi-Track Diplomacy theory which will explain the diplomatic channels used by the United States in the policy of restoring diplomatic relations with Cuba.

\subsection{Theory of Foreign Policy}

The end of 2014 became a new point marked by the goodwill of the United States towards Cuba to improve diplomatic relations between the two who had been more monotonous for 50 years. The United States' foreign policy regarding the restoration of diplomatic relations with Cuba has undoubtedly become a foreign policy that has shocked the world as well as a wind of change that is awaited by the international community (The White House 2016).

The foreign policy of a country, in general, is the result of a series of decisions relating to phenomena between nations. Usually, these policies are issued by individual states to address issues that develop with other countries. This study meant to explain the strategies adopted by the United States government under the leadership of Barack Obama. Researchers used the Foreign Policy Making Theory approach, according to William D. Coplin, in his book entitled Introduction of International Politics, which was translated by Mercedes Marbun in his book entitled Introduction to International Politics.

When analyzing a country's foreign policy, it must get questioned how the leaders of the country (international policymakers) act whether, without consideration or vice versa, these actions seen as the result of three concerns that affect foreign politicians. The three factors are; first, domestic political conditions, second is economic and military capabilities, and the third is the international context, namely the specific position of a country concerning other countries (Marbun 1992).

\subsection{Multi-Track Diplomacy}

Louise Diamond and John McDonald said that multi-track diplomacy is a diplomacy concept that explains the process of world peace in the international system through a combination of government path diplomacy, group path diplomacy, and individual track diplomacy (Diamond and Donald 1996). The main objective of multi-track diplomacy is for the sake of creating world peace to peacebuilding, which integrated using soft power.

The use of soft power in creating peace is reflected in the implementation of quiet diplomacy, namely establishing cooperative relations with other countries. Multi-track diplomacy related to obtaining order is to take a systematic approach to understand the structural nature of international development. Peacebuilding activities create a mid-level structure, namely to develop a system of institutional behavior and actions to support the realization or implementation of peace, and this done by building an economic, military, and community infrastructure that provides strength and realism through a peace system.

The structure of peacebuilding in multi-track diplomacy is essential because any conflict cannot be resolved by itself. Achieving peace needs to be balanced with the involvement of the government and community sectors. This involvement can help structural peace activities, including economic development programs, strengthening 
democracy and governance, supporting the creation of communities and indigenous organizations that promote peace. Structural peacebuilding by combining government and community sectors is undoubtedly more effective in overcoming world problems.

The concept of multi-track diplomacy consists of nine diplomacy tracks which are a combination of various diplomacy actors, namely:
- Track One : Government
- Track Two : Nongovernment
- Track Three : Business
- Track Four : Private Citizen
- Track Five : Research, Training, and Education
- Track Six : Activism
- Track Seven : Religion
- Track Eight : Funding
- Track Nine : Communications and Media

In this research, the multi-track strategy undertaken is diplomacy track one "Government," diplomacy track two "Non-Government." The policy of restoring diplomatic relations between the United States and Cuba uses diplomatic channels in its implementation. Diplomacy track one is a process of peacebuilding and peacemaking actions between countries at the government level that seeks to form, manage and improve systems of international relations, trust, confidence, mediation, crisis intervention, conflict resolution, even to prevent violence and secure the national interests of the state such as the economy, trade, politics, human rights, science, culture, and academia, because, at present society, culture, religious identity groups, ethnicity, or political groups of interests, and citizens also have a formal position in the global system.

Track One Diplomacy or commonly known as official diplomacy, De Magalhaes (1988) describes official diplomacy as a foreign policy instrument for the formation and development of contacts between governments of various states through the use of intermediaries that are mutually recognized by each party. The most important feature that distinguishes Track One diplomacy from all other forms of diplomacy is its formal application at the state level. This follows specific protocols for which each country is a signatory. Track One Diplomacy usually get seen as the primary peace tool of the state's foreign policy. This gets done by diplomats, high-level government officials, and heads of state, and middle-level officials can influence the structure of political power.

The term of Track Two Diplomacy was coined in 1981 by Joseph Montville. Montville that use the time to denote informal conflict resolution dialogues conducted by non-governments or conducted by people or diplomatic partners. Diplomatic professionals must better understand such a conversation.

Montville defines Track Two as an informal, informal interaction between members of an enemy group or country with development goals that influence public opinion and organize human and material resources in ways that might help resolve conflicts. Practitioners from the track two diplomatic channels are not diplomats. Diplomats are only used to refer to people who officially represent their country. At the same time, some twotrack processes may be closely related to and approved by official diplomacy and official 
officials.

\section{Research Method}

The research approach that will get used in examining the US Foreign Policy Policy in the context of Restoring Diplomatic Relations with Cuba in 2015-2016 is qualitative. A qualitative approach uses the natural environment as a source of data. This research using a qualitative approach will be descriptive-analytic and inductive. The data obtained is based on observations, document analysis, and written in narrative form.

The US Foreign Policy Research in the context of Restoring Diplomatic Relations with Cuba in 2015-2016 will use secondary data. Secondary data is data obtained by researchers from various kinds of literature such as books, journals, papers, newspapers, or articles from internet sources from official websites relating to research problems investigated by researchers.

Data collection techniques that researchers use in the United States Foreign Policy Research in the context of Restoring Diplomatic Relations with Cuba in 2015-2016 is library research. Library research is a way of collecting data from the literature relating to the subject matter or topic under study. The writing can get sourced from books, documents, journals, newspapers, or magazines, as well as articles from official websites that are relevant to the research topic.

\section{Results and Discussions}

\subsection{History of the United States' Bilateral Relations with Cuba}

Explaining bilateral relations between the United States and Cuba is indeed a bit complicated, given the dynamics of the two that are inseparable from the ups and downs of relationships. The dynamics of relations between the two countries began in the early 1900s. Cuba gained independence from the Spanish colonial government when the Spanish-American war ended in 1898, but Cuba had not yet had time to enjoy its freedom. The United States first began military occupation in Cuba in 1899.

On March 2, 1901, the United States Congress passed the Plat Amendment (Lee and Park 2016, 187) which states the United States could intervene in Cuba's foreign affairs and international economic problems for "preservation of independence" and "protection of life, property and individual freedom" in Cuba (Bedolla 2009, 123). This automatically limited Cuba's sovereignty as an independent state, until finally in 1934, the then President of the United States, Franklin D. Roosevelt, revoked the amendment and turned it into a Neighbors Policy with Latin America (Lee and Park 2016, 190).

Cuba also has a new leader under the auspices of Fulgencio Batista. The Batista regime is indeed very close to the United States, so that the influence of the superpower is increasingly evident in Cuba both domestically and internationally. This period is better known as the period of semi-colonialism for Cuba. But on the other hand, there is an antiUnited States spirit that has taken root and motivated the rise of Fidel Castro. Cuban hostility towards the United States comes not only from the consequences of a small force against a large army but also the result of both their history. 
The development of US relations with Cuba shortly after the victory of the Cuban Revolution of 1959 had led the United States to recognize Cuba's interim government. Then on 15 to April 26, 1959, Fidel Castro visited the United States in private to discuss bilateral relations between the two countries with then-Vice President Richard Nixon (Shixue 2015, 84). But what happened was unexpected because, after the visit, relations between the United States and Cuba deteriorated and led to a cold war between the two. There are two arguments to answer the deteriorating relations between the United States and Cuba. Firstly, one of the attributes of harm to Cuban socialists and secondly, the Cuban government's policies are not in line with the interests of US financiers (Shixue 2015, 85).

In May 1960, the United States stopped giving aid to Cuba. Then in October 1960, the United States began a trade embargo on Cuba, and the final occurred on January 3, 1961, when the United States severed diplomatic relations with Cuba. President John F. Kennedy, on January 20, 1961, after officially taking office, declared the implementation of a military invasion of Cuba. On April 15, 1961, US forces launched an attack by attacking several airports in Cuba which continued on April 17 by sending 1500 US troops to the Bay of Pigs (Shixue 2015, 85) who were in a state of a dispute at the time to overthrow the Cuban government by force in the region.

The reaction of the United States to Cuba turned out to continue, as evidenced on February 7, 1962, the United States began imposing an economic embargo on Cuba. Following decision No. 3447 explained that the US embargo on Cuba occurred because Cuba had violated the goals of the United States system and was too allied with communist countries such as China and the Soviet Union. In October 1992, President George H.W. Bush signed the Cuban Democracy Act or known as The Torricelli Law in Miami (Shixue 2015, 96), one of the most populated areas in the United States of Cuba by immigrants. The agreement stipulates that ships entering the port of Cuba get prohibited from entering the United States for six months. Besides, the US companies in third countries get forbidden from doing business with Cuba, and finally, the United States will impose sanctions on any country that does business with Cuba.

The Clinton Administration also continued policies that considered to promote change through pressure on Cuba. In June 1996, the United States adopted a more stringent policy through the Helms-Burton Act (Shixue 2015, 86) in which regulates such matters as a ban on third countries selling Cuban products to the United States, banning individuals who do business with Cuba from entering the United States. , allowed citizens of the United States whose properties were affected by the nationalization of Cuba in the era of Fidel Castro to submit claims through US justice and the last to ban international organizations from giving loans to Cuba. But in July 1996, President Clinton finally announced the suspension of the adoption of the Helm Burton Act related to the many demands of foreign companies in US justice that rejected the rules in the Helm Burton Act.

\subsection{Background on the Restoration of Diplomatic Relations between the United States and Cuba}

On May 12, 2002, President Jimmy Carter arrived in Cuba (Shixue 2015, 86) and became the first president to visit Cuba after an embargo issued by the United States 
against Cuba. During his visit, Carter visited a research institute in Havana to ensure that Cuba did not lie to the United States and the world about the possibility of developing biological weapons. Carter briefly stated in one of Cuba's information media as follows "Our two countries have trapped in a state of destructive hostility for 42 years. Now is the right time to develop our relationship by changing the way of thinking and dialogue between the two countries because the United States is a big country so that we will start first ". Although he had stated this, the evidence of the hostility policy between the United States and Cuba has not changed.

On July 31, 2006, when President Fidel Castro hospitalized because of his deteriorating health (Shixue 2015, 87) had marked the United States to start plans to subvert the current regime in Cuba. In other words, the United States does not want to see Raul Castro, the latest Cuban leader who is the younger brother of Fidel Castro, as the same figure as his predecessor. Raul Castro is present as a new leader who will take Cuba in a new direction even though it is still in the socialist realm.

On April 13, 2009, under the administration of Barack Obama, the President of the United States of America announced the lifting of restrictions on traveling from the United States to Cuba and vice versa (Shixue 2015, 87) primarily for reasons of visiting family and allowing remittances to Cuba and allowing US telecommunications companies to enter into the Cuban market and make cooperation in communication and satellite networks in Cuba.

The motivation of the United States to improve relations with Cuba is (Shixue 2015, 88-90)

- President Obama realizes that US sanctions against Cuba are a policy that does not work

- The United States no longer wants to lose the Cuban market, which is very promising as the backyard of the United States.

- Many international and domestic pressures are asking the United States to restore relations with Cuba

Besides, from the Cuban side, in terms of restoring relations with the United States, it can be understood more rationally and more efficiently. Considering that during the period of embargo sanctions imposed by the United States, Cuba had suffered economic losses of 1.1 Trillion US Dollars, and Cuba itself did not succeed in adding capabilities. Its capital and technology during the embargo (Shixue 2015, 91). So accepting this offer of restoration of relations will provide an opportunity for Cuba to be active on a regional and international scale so that it can catch up during the embargo.

The timeline for US relations with Cuba began to thaw on December 17, 2014, and President Barack Obama moved to improve relations with Cuba. This decision reached after 18 months of covert negotiations between the United States and Cuba and the release of US aid contractor Alan Gross. It also followed by an announcement of a plan to restore relations in the coming months to ease travel and financial restrictions in Cuba. The report has paved the way for the United States with Cuba to restore diplomatic ties, re-open the 
embassy, and potentially eliminate the embargo.

\subsection{Implementation of the Restoration of US and Cuba Diplomatic Relations}

In the political field, the United States continues to take the initiative of meetings and official state visits from the head of state to the level of congressional officials. Also, it was not only US politicians and power holders who came to Havana, but also official Cuban representatives actively visited Washington both in terms of negotiations and state visits. The United States also took the initiative to conduct a review of the status of the Terror Sponsoring Countries, which handed down to Cuba in 1982. Moreover, Cuba's close relations with the left-wing Soviet Union at the time, making Cuba one of the list of countries sponsoring terror created by the United States. A review of the status issued by the secretary of state and reported directly to President Barack Obama at the time.

The 2015 Summit of the Americas in Panama was also a big jump because, in that year, finally representatives from Cuba were included in the meeting and had the same rights and obligations as all delegations from other American countries. The success of Cuba that took part in the meeting was inseparable from the help of other American states, asking the United States to include Cuba in a session based on an agreed American congress. The political field will undoubtedly become a sector that is supervised and worked on by the state and the ranks of the Barack Obama administration. President Barack Obama himself is optimistic that the restoration of diplomatic relations with Cuba in the political field will produce agreements that benefit the two countries. Good political relations will create conducive conditions for foreign policy for the two countries so that other sectors such as the economy, business, society, and culture can also run smoothly.

The ongoing state visit to negotiations between the United States and Cuba is also an attempt to equalize the perception of the future relations between the two countries and equalize the desires to be achieved by each state so that no party feels aggrieved through the restoration of this relationship. Obama's visit on March 21, 2015, brought a variety of agendas, one of which discussed economic relations with Cuba. Although the embargo still cannot be abolished, economic relations began to show an increase. The United States finally allowed corporations to invest in Cuba, which was marked by the entry of the World Wide Starwood Hotels \& Resorts network. Starwood officially expanded to Cuba as well as becoming the first US company to work on the business in Cuba. There are still several companies such as Marriot International Inc., and AT\&T Inc. has requested permission from the United States Treasury to be allowed to enter Cuba (Shixue 2015).

Since the political reconciliation carried out by the two countries, the Cuban tourism sector has contributed significantly to the Cuban economy. Noted international tourist visits to Cuba rose $40 \%$ in 2015. Tourists from the United States devoted to this record. In addition to the hotel business, two small companies in the United States are trying to build a tractor business, the Cleber Tractor Company to help agriculture in Cuba so that production costs can be reduced and increase income. Besides, fruit and vegetable entrepreneurs in the United States will also enter Cuba to facilitate the distribution of food to restaurants or large kitchens in Cuba (Lee and Park, 2016).

The freezing of trade relations between Cuba and the United States is slowly melting. The charcoal commodity has become knitting of trade relations, which has stalled 
for the past 55 years. The charcoal will be the first commodity exported by Cuba to the United States in the last half-century. Certainty about this came after the communist stateowned company, Cuba Export, signed a trade agreement with a company from the United States, Cabana Trading.

The agreement is wide-reaching for the restoration of US relations with Cuba, according to Coabana Trading President Scott Gilbert, after the signing of the deal in Havana, Cuba. Under the agreement, Cuba Export will sell charcoal to Coabana Trading at a price of US $\$ 420$ per ton. Cuba Export will start the trade by sending 40 tons of marabu charcoal, which is made from marabu wood from Africa, on January 18, 2017, or two days before Donald Trump's inauguration. During this time, Cuba Export exports 40,000 to 80,000 tons of charcoal per year. Still, the majority of its shipments aimed at European markets, such as Italy, Germany, and several other countries.

This trade cooperation took place amid the enactment of a trade embargo from the United States to Cuba. The business activity can take place because of the approval of the President of the United States, Barack Obama. Obama's decision has been a pioneer in restoring diplomatic and economic relations between the two countries as he has agreed with Cuban President Raul Castro since 2014.

The United States Congress, which is dominated by Republicans, has indeed rejected the full lifting of an embargo on Cuba because it considers the country ruled by a dictatorial regime. But, Obama, who will soon end his term on January 20, 2017, took the initiative to relax trade restrictions so that particular products from the Cuban peasant cooperative could get exported to his country. In the future, many things, such as human travel arrangements and the movement of goods and services from the United States to Cuba or vice versa, will be even better. This will be fully supported, such as the provision of commercial flights from airports in the United States to Havana on a constant periodic basis. Then also, the business and cruise ship cruise schedules continue to be improved. In the field of procurement of goods and services from the United States to Cuba and vice versa is supported by establishing the same export policy between the United States and other countries. Besides, the system of banning direct business relations with Cuba has also been abolished by the United States so that now anyone can conduct business relations with Cuba, both individuals, and corporate forms.

The restoration of diplomatic relations between Cuba and the United States is also significantly influential in the socio-cultural field. The socio-cultural sector is the secondlargest field that has had the effect of restoring diplomatic relations between the two countries. Favorable facilities for the citizens of the United States and Cuba have become very important in the restoration of diplomatic relations. Starting from the financial flow, the freedom to visit each country is also about the rotation of goods and services as basic life needs are also getting better.

Both countries, especially the United States, are aware that to rebuild relations with Cuba will undoubtedly be more accessible when the peoples of each country have opened up to each other. Therefore, people to people diplomacy is strongly encouraged by the United States in dealing with Cuba. This diplomacy will undoubtedly be instrumental and can provide the right stimulus for economic and political relations between the two countries. 
Collaboration between educational institutions, research, and technology also continues to increase after the policy of restoring diplomatic relations was officially initiated. The cooperation gets expected to be able to provide educational and scientific equality between the people of the United States and Cuba because the effects of the US embargo on Cuba have made the island nation a few steps behind the United States in terms of technological mastery. When the knowledge of technology is the same and equal, it expected that Cuba could provide a better life guarantee to its people, especially when experiencing a disease that is endemic in the world today.

Besides, communication access in Cuba also gets a fresh breeze with the restoration of this relationship. Some US telecommunications companies have started to enter Cuba, and this has a significant progress effect on the quality and quantity of telecommunications in Cuba, both in Cuba and internationally. The presence of the US telecommunications company encourages the availability of internet networks in almost all islands in the country. So that internet access is no longer an expensive item for the Cuban people.

The cultural exhibition is also one of the activities that have been initiated by the two countries. Like Cuba, which often holds cultural exhibits in the United States. It meant to introduce the status and the culture of both countries. United States people can get to know Cuba, especially those who still have Cuban blood of Cuban descent. Cuban people will also get to know the United States better and be able to provide a new perspective after 50 years of being present as a country that complicates Cuba with its embargo policy.

These cultural activities hoped for the people of both countries, especially the young generation, to get a new perspective in seeing their neighbors. This brand new point of view expected to change the bad image that each country once had. So that the cooperation between the two countries becomes closer and the dream to normalize relations between the two countries can realize.

\subsection{Implications for the Restoration of Diplomatic Relations for the Two Countries}

\subsubsection{Opening the Embassy}

Seeing the progress shown in the ongoing process of restoring diplomatic relations between the United States and Cuba, the two countries considered that it was time for the United States and Cuba to re-open their respective embassies. And both countries need to have embassies in each other's countries. The decision to re-open the two countries' embassies get driven by the fact that for more than 53 years, the task of the representatives of each country was carried out by the United States Interest Section in Washington DC and Havana.

The existence of the United States Interest Section not considered to have fulfilled the actual duties of state representatives, bearing in mind that the United States Interest Section is only a form of institution derived from embassies. So, to answer the need for an official representative office, the United States and Cuba agreed to hold bilateral talks related to the plan to re-open embassies in their respective national capitals.

After a reasonably long process, finally, on July 20, 2015, the United States officially opened its embassy in Cuba (Felter, Lee, McBride, \& Renwick, 2017). On the same day, Cuba also opened its embassy to the United States as a form of reciprocal 
diplomatic relations restoration efforts. The building, which was originally a United States Interest Section building in Havana and Washington DC, has now changed its function to become the United States embassy in Havana and the Cuban embassy in Washington DC. The re-opening of the US and Cuban embassies is a sign of restoring diplomatic relations between the two countries.

\subsubsection{Health Quality Improvement}

Cuba is a country that is famous for its health system, so this country makes health as a pioneer in establishing relations with other countries. Many Cubans have been sent to conflicting countries or are still low in health services as volunteers. Even though it is a developing country, Cuba can provide health facilities for its people. There have been 14,671 Family Physician Offices, 444 Health Centers, 162 Dental Clinics, 267 Hospitals, $272 \mathrm{MCH}$ Centers, 144 Elderly Health Centers, 32 Disabled Health Centers, 25 Blood Banks, and 12 Research Centers.

Many Cubans who were getting sent abroad volunteered, such as to Haiti since 1998, when an earthquake occurred that left 230,000 Chinese citizens dead during the tsunami disaster in Indonesia, Africa, China, and many more. With the large amount of assistance provided by Cuba to many countries, the international community is interested in helping health there to be even better.

When Cuba is famous for the country that has the best health level in the world, it is different from the United States, which has a high enough budget for the health sector, but get listed as having the highest mortality rate at a young age. The death rate with unclear reasons is high enough.

In 2011, Britain ranked first with the highest health level among the 11 wealthiest countries, namely Switzerland, Sweden, Australia, Germany, the Netherlands, Norway, France, Canada, and the United States, only spending \$3,405 per capita on health costs compared to the United States spends $\$ 8,508$ per capita. For this reason, Cuba and the United States together maximize their respective health fields. Cuba is already an expert in the health sector but is still constrained by sophisticated equipment and dental health equipment due to cost and the United States, which has advanced in the field of technology but has not been as good as the health of the Cuban State. So that these two countries focus on a few points:

- Collaborate to develop more in the fields of biotechnology, vaccines and tropical medicine with universities and government agencies such as the National Institutes of Health (NIH) and Centers for Disease Control (CDC) in the United States and The Carlos Finlay and Pedro Kourt Institutes, The Center for Genetic Engineering and Biotechnology (CIGB) and The Center for Molecular Immunology (CIM) in Cuba.

The private sector of the United States promises to improve the system in Cuba and enhance development with public assistance from both parties to create its private sector in Cuba. 
- Learn from Cuba, which has various medical measures to prevent someone from contracting a disease (preventive medicine) and primary care in the regulation of limited resources.

- The United States and Cuba actively coordinate with other countries on health issues also help low-income countries build affordable health services.

In addition to some of the points above, the United States follows up on vaccines and drugs made previously by Cuba like the lung cancer vaccine, cimavax, and distributed for free to 1000 of its citizens will soon be clinically tested by the Food and Drug Administration (FDA). Besides developing further diabetes drugs, heberprot. This drug gotten created in Cuba since 2006 and has gotten tested on its citizens and 170,000 patients in 23 countries. For reasons of the embargo, this drug does not enter the territory of the United States. However, the establishment of relations between the two countries has made the FDA in the process of researching the ingredients in this drug, based on US citizens' standards.

\subsubsection{Improvement in the Technology Field}

Technology is critical to be developed by a country. As a country that is closed to the outside world, Cuba still maintains its traditional values. If telecommunications and the internet are commonplace, it is different in Cuba. There would be no means of communication, even if they were undoubtedly gotten obtained from outside Cuba. There is no free internet access. Only for intellectuals and workers, also still charged again with the cost of Wireless Fidelity (Wi-Fi), which is quite expensive, around $\$ 4.5-\$ 7$ per hour, which is not comparable to income in Cuba. If you need help from others, there is no other way but to meet directly with the person concerned. Vehicles in Cuba are still very classic, unlike other foreign countries.

It makes the Cuban people scared of being left behind by other countries. When all was able to access the internet, Cuba was not able to reach it. Prolonged connections and inadequate equipment become obstacles - another case of United States technology that can not get doubted. Until now, the United States has improved its internet facilities, which are recognized to be the main milestones in telecommunications. It got realized that the internet helps increase economic productivity, education, health, democracy, and human rights.

The normalization of Cuban relations with the United States brought a gradual change in Cuba. Focusing on improving communication, the government has added hotspots in several areas to reduce the cost of internet usage. Although not all citizens can access the internet at home, but are accessible at some points. Besides, the US telecommunications company (Sprint and Verizon) agreed with the Cuban telecommunications company at the end of 2015.

The increase was also supported by the sending of four Cuban students to the New York Startup Company some time ago. It hoped that they would be able to get enough supplies 
to innovate in their home region. The United States has promised to continue to coordinate with Cuba to continue to improve telecommunications in Cuba.

Besides, in the field of communication, technology is also developed in the economic sector. If in the past, only knew cash payments, now Cubans can afford to pay using a credit card. US citizens who come to Cuba do not need to worry about making transactions. Multinational companies in the financial services sector American Express (AXP) and Stonegate Bank issued Master Cards so that their customers can use credit cards in Cuba.

\subsubsection{Environmental Quality Improvement}

The establishment of relations between Cuba and the United States also has an impact on the environment. After the two heads of government held a meeting, the first collaboration gotten carried out to discuss environmental issues. Because of limited funds, Cuba has not gotten maximized in protecting its ecosystem. Fear of the increasing number of tourists coming to Cuba and damaging the environment is one of the reasons for the emergence of cooperation in this field.

When normalization gotten carried out, scientists working for national parks in Florida and Texas will collaborate with scientists from the Guanahacabibes national park in Cuba. These sanctuaries have similarities in terms of fish and coral species, so it hoped that this collaboration would seek ways to preserve vulnerable ecosystems as a result of opening up marine ecosystems as tourist attractions. Cooperation in the environmental field is one of the most intense collaborations carried out. Last October, the two countries were in the process of completing an agreement in the field of marine conservation. Cuba and the Environmental Defense Fund (EDF) initiated the protection of shark populations, recorded fishing activities by ships, and developed long-term conservation plans. In April, US scientists and Cuban scientists circled the island using cruises aimed at research on larvae of bluefin tuna, which is a threatened species and has a high sale value. Cuba's marine ecosystem is one of the best areas for conservation, with a large number of untouched corals and large populations of sharks and turtles. But the ecosystem has the potential to be damaged, considering this cooperation opens the door for foreign tourists visiting this country.

In addition to fear of damage to the ecosystem with many tourists coming, other worries come along with the increased oil exploration by Cuba. This then motivated the discussion between the two countries to produce an agreement to prevent oil spills that would cause damage to coral reefs and marine ecosystems in both countries. The United States has signed a Memorandum of Understanding (MOU) in Havana to collaborate with Cuba on the conservation and management of marine parks. The MOU brings the two countries together to protect turtles, reef fish, sharks, and other endangered marine species.

The Cuban and American governments have also made A Joint Statement on Environmental Cooperation, which allows the two countries to work together to improve scientific exchange and dialogue on environmental issues, including climate change, overfishing, marine pollution, loss of flora and fauna diversity. The relations between the United States and Cuba are intertwined, of course, involving its citizens. In the past, if citizens from each country wanted to come to the United States or Cuba, they would have 
to group quite high and pass some pretty strict and complicated rules. However, after the restoration of relations carried out, the government of the two United States countries has removed Cuba from the list of terrorist source countries and has also put in place new rules if. The people of the two countries can now travel individually or known as people to people.

Cuban society can easily access US banks and also get jobs there, especially for those who have immigrated to the United States. The visit in question is a family visit, government affairs, activities of journalists, research, religious events, performances/exhibits not included in the list of visits allowed.

Those who want to come must fill out a form stating their visit for educationalrelated purposes. The deadline given to stay is for five years and to inform you what activities will get carried out while there. The agreement to restore the flight got signed by the US Transportation Minister, Anthony Foxx, and his Cuban partner, Adel Izquierdo Rodriguez. There will be more than 100 flights per day between the two countries.

\subsubsection{Student Exchange}

Over time, the United States government increasingly intensively supported the decision of the Cuban government to begin adopting democratic norms in its administration. The initial step to be taken by the Cuban government in connection with starting to adopt democratic standards is to provide adequate facilities for its citizens who have been under government restraint. The initiative is a clear illustration that the Cuban government is serious about fixing human rights issues in the country. Realizing this, the United States is trying to help Cuba in achieving its ideals. Furthermore, the United States government is willing to cooperate with Cuba to support the steps of the Cuban government.

The real manifestation of the seriousness of the United States to return to nostalgia, one of which is shown by providing opportunities for Cuban students who want to do student exchanges at the best universities in the United States. Thus every student or student who has the desire to carry out a better education will be facilitated in getting an education permit in the United States. Besides, the United States government also provides opportunities for Cuban academic groups to research in the United States; another goal of this policy is to improve the people to people approach among the United States-Cubans.

\subsection{Challenges Towards the Normalization Process}

First, it talks about the US economic embargo on Cuba. Obama has acknowledged that the political blockade of Cuba has proven to be a failure. However, until now, Obama has not been seen as actually stopping the blockade policy. Cuban President Raul Castro has repeatedly stressed that the most fundamental problem that hampered Cuba's diplomatic normalization with the United States was the embargo. Cuban Foreign Minister Bruno Rodriguez Parrilla claims, the US embargo has made Cuba lose 1.1 trillion US dollars. Not only that, but the restriction also made it difficult for Cuba to get a cure for heart disease and AIDS for its people. While according to the United Nations, the embargo caused Cuba to lose 117 billion US dollars and also caused Cuba to struggle to move its economic wheels. 
Second, the issue of Guantanamo prison. Until now, the United States has occupied part of Cuba's territory, the Guantanamo Bay. In that region, even the United States makes individual prisons known for the terrible types of punishment imposed in these prisons. When Obama and most Americans consider Cuba as a violator of human rights because it severely limits the rights of its citizens, on the other hand, the United States forgets that they are also practicing territorial crime on the Cuban mainland precisely in the Guantanamo prison.

Third, immigration policy. One big obstacle to the normalization of the United States with Cuba is the politics of US immigration, called "wet feet, dry feet," which allows Cubans who reach the mainland to settle in the United States and renounce their citizenship. For Cuba, this is a cruel policy. On the one hand, the United States imposed an economic embargo on Cuba, which led to the economic paralysis of Cuba. It is what forced many Cubans to seek their fortune in the United States.

But on the other hand, when they headed for the US, they were intercepted. Many Cubans gotten killed on the way. Not a few submerged in the Gulf of Mexico. Some are subject to traffickers if they want to take another route. Only those who made it to the United States were allowed to stay and get special treatment. They don't need visas and similar documents. Then after living there for a year, they can acquire United States citizenship status. For the Cuban government, this United States policy triggers the practice of immigration without rules, which often puts immigrants on dangerous journeys.

Fourth is the problem of democracy. Aside from the above issues, the Obama administration has not yet let go of the United States' ambition to encourage "regime change" in Cuba. That is, the United States continues to interfere in Cuba's internal affairs and sovereignty. On the sidelines of his visit, President Barack Obama still found time to meet with Cuban dissidents. The United States also continues to pour funds into organizations or individuals in Cuba to encourage regime change.

\section{Conclusions and Recommendations}

\subsection{Conclusions}

The implementation of US foreign policy research in the context of restoring diplomatic relations with Cuba in 2015-2016 was motivated by the first, President Obama realizing that US sanctions against Cuba were an unsuccessful policy. Secondly, the United States no longer wants to lose the up-and-coming Cuban market as a backyard of the United States. And third, a lot of international and domestic pressure is asking the United States to restore relations with Cuba. From these three points, it is clear that all efforts and actions carried out by the United States and Cuba, both at the government and community level, are merely for the sake of achieving new mutually beneficial relations for both countries.

The fact that the economic embargo imposed by the United States on Cuba did not have a significant impact on the United States made Barack Obama became aware that the embargo policy adopted by the United States for almost 53 years on Cuba had caused losses to both countries. The United States, which was led by Barack Obama, initiated for the restoration of diplomatic relations between the United States and Cuba. However, 
indeed, this was not an easy decision considering that Fidel Castro would not easily let the United States enter Cuba after a bad past.

The two countries succeeded in starting the restoration of diplomatic relations. Although it was still far from being a form of restoring diplomatic ties between the two, the United States, as a vast country that has embargoed Cuba for 53 years, must finally realize that they are missing a promising basis from Cuba. The implementation of re-opening policy forms between the two countries as an application of the normalization of diplomatic relations between the United States and Cuba marked by opening embassies of each country in the capitals of the countries concerned. Besides, the implementation of the policy of restoring diplomatic relations between the United States and Cuba can get seen in terms of political, economic, and social culture. Although, of course, the three points are different achievements and still dominated by the industrial, socio-cultural sector and lastly by politics.

The implications of re-opening diplomatic relations between the United States and Cuba certainly occur in both countries. The United States and Cuba have at least benefited from this policy. The most significant implications can get seen in improving the quality of health, technology, environmental and social fields of the two countries.

However, it cannot get denied that to be able to achieve normal relations as two independent and good relations countries, the United States and Cuba still experience some obstacles. These constraints include. First, Cuba is demanding the return of Guatanamo as Cuba's territory. Second, Cuba wants compensation from the United States to Cuba for losses incurred during the economic embargo that the United States has applied to Cuba, and third, Cuba asks the United States to stop interfering in Cuban government affairs.

The United States also gave several conditions if it wanted to go to the stage of normalizing relations with Cuba, among others, Cuba had to be willing to change its government system to democracy and uphold human rights values. The United States considers that the Cuban government system is still far from democracy so that it will continue to create injustice for the Cuban people themselves, and this democratic government can later promote better implementation of human rights values in Cuba.

\subsection{Recommendations}

- US foreign policy research in the context of restoring diplomatic relations with Cuba in 2015-2016 has indeed revealed various facts about the relationship between the United States and Cuba from 2015 to 2016. The advice formed from this research is

- The United States Government must be able to maintain improved relations with Cuba while maintaining political, economic, and socio-cultural cooperation.

- The use of diplomacy can be improved, considering that of the nine existing routes, the United States and Cuba have only used two ways. So many other pathways can get used to building closer relationships. 
- Outputs or outcomes that have a positive influence on the two countries, such as in the fields of environment, technology, and education, can continue to be maintained given that the restoration of diplomatic relations is not the final result but only a first step towards normalization of better relations.

- With the four reasons for failure to normalize, researchers can further explore the steps towards normalizing relations between the United States and Cuba. 


\section{BIBLIOGRAPHY}

\section{Books}

Ambarwati, and Subarno Wijatmadja. Pengantar Ilmu Hubungan Internasional. Malang: Intrans Publishing, 2016.

Amstutz, R. Mark. International Conflict and Cooperation: An Introduction to World Politics. Dubuque:: Brown \& Benchmark, 1995.

Bedolla, Lisa Garcia. Latino Politics. Cambridge: Polity Press, 2009.

Graff, James E. Dougherty \& Robert L. Pfaltze. Contending Theories of International Relations: A Comprehensive Survey. New York: Longman Publisher, 1986.

Hara, Abubakar Ebi. Pengantar Analisa Politik Luar Negeri dari Realisme sampai Konstruktivisme. Bandung: Penerbit NUNSA, 2011.

Marbun, Marsedes. Pengantar Politik Internasional. Bandung: Sinar Baru, 1992.

Rudy, May. Hubungan Internasional Kontemporer dan Masalah - Masalah Global.

Bandung: Refika Aditama, 2003.

Sugiyono, Prof. Dr. Memahami Penelitian Kualitatif. Bandung: ALFABETA, 2014.

The Aspen Institute. US Policy Toward Cuba First Conference. Washington, DC: The Aspen Institute, 2000.

Yani, Anak Agung Banyu Perwita \& Yanyan M. Pengantar Ilmu Hubungan Internasional. Bandung: PT Remaja Rosdakarya, 2005.

\section{Journals}

Atthariqa, Andry. "Dampak reformasi Ekonomi dan Politik Kuba Terhadap Hubungan Bilateral dengan Amerika Serikat Tahun 2008-2016." Jurnal Online Mahasiswa FISIP Universitas Riau (Universitas Riau), 2017: 1-11.

Hermann, M. G., and C. F. Hermann. Who Makes Foreign Policy Decisions and How: An Empirical Inquiry. London: International Studies Quarterly, 1989.

Kalangi, Irene Jessica. "Hubungan Bilateral Kuba-Amerika Serikat Pada Masa Pemerintahan Raul Castro." Hubungan Bilateral Kuba-Amerika Serikat Pada Masa Pemerintahan Raul Castro. Makassar: Universitas Hasanuddin, 2016.

Lee, Wootae, and Seong-Yong Park. "Similiar but Divergent Pathways: US-Cuba and USNorth Korea Relations." Pacific Focus, 2016: 187.

Papasi, J M, Dewi Triawahyuni, and M Bayu Saputra. "Pengaruh Idiosyncratic Raul Castro dalam Hubungan Luar negeri Kuba - Amerika Serikat." Global Political Studies Journal (Universitas Komputer Indonesia) 4 (December 2015).

Persada, Putra. "Penolakan Amerika Serikat Terhadap Permintaan Pengembalian Teluk Guantanamo Oleh Kuba." E-Journal Ilmu Hubungan Internasional FISIP Universitas Mulawarman, 2017: 315-330.

Pradana, M. Gamma Fajar. "Kebijakan Pemerintahan John F. Kennedy di Amerika Serikat pada Tahun 1961-1963." Kebijakan Pemerintahan John F. Kennedy di Amerika Serikat pada Tahun 1961-1963. Daerah Istimewa Yogyakarta: Universitas Negeri Yogyakarta, 2014. 
Shixue, Jiang. "Improvement in US-Cuba Relations and Their Implication." China International Studies, 2015: 84. 